\section{Low Temperature Storage of Almond Pollen}

\author{
P. Martínez-Gómez and T.M. Gradziel ${ }^{1}$ \\ Department of Pomology, University of California, Davis, CA 95616
}

E. Ortega and F. Dicenta

Departamento de Mejora y Patología Vegetal. Centro de Edafología y Biología Aplicada del Segura-Consejo Superior de Investigaciones Científicas, P.O. Box 4195, E-30080 Murcia, Spain

Additional index words. Prunis dulcis, pollen, viability, pollen germination, cryopreservation, breeding

\begin{abstract}
Pollen of the California almond cultivars Nonpareil, Ne Plus Ultra, Sonora, and Peerless was evaluated for viability following storage over 12 months at $4,0,-20$, and -80 ${ }^{\circ} \mathrm{C}$. The proportion of viable pollen exceeded $80 \%$ for all cultivars and for all temperatures evaluated after 2 months of storage. Following 12 months of storage at $4{ }^{\circ} \mathrm{C}$, germination decreased to $8 \%$ for 'Nonpareil', $10 \%$ for 'Ne Plus Ultra', 50\% for 'Sonora', with no germination observed for 'Peerless'. Storage at sub-freezing temperatures maintained pollen viability above $70 \%$ in 'Nonpareil', 'Ne Plus Ultra', and 'Sonora' and above $40 \%$ in 'Peerless'. Cultivars differed significantly in their tolerance to low temperature pollen storage. Within cultivars, differences in pollen germination following storage at $0,-20$, or $-80{ }^{\circ} \mathrm{C}$ were nonsignificant.
\end{abstract}

The genetic improvement of almond [Prunus dulcis (Mill.) D.A. Webb] cultivars frequently require pollen storage because of the asynchronous flowering among genotypes. Hybridization between late and early-flowering genotypes requires short-term pollen storage since the quality of almond pollen deteriorates rapidly at moderate temperatures and humidities (Martínez-Gómez et al., 2000). In addition, the pollination of early-flowering cultivars with pollen from late-flowering cultivars, or the use of pollen from other countries with different climates, may require long-term storage of up to 1 year.

Low temperatures have been reported effective for long-term preservation of pollen from nut trees. Cryopreservation at temperatures to $-196{ }^{\circ} \mathrm{C}$ has been studied. However, a comparison with long-term storage temperatures near $0{ }^{\circ} \mathrm{C}$ were not included (Barnabás and Kovács, 1997; Jiang and Gao, 1989; Luza and Polito, 1985, 1988; Parfitt and Almehdi, 1984; Polito and Luza, 1988). The viability of almond pollen can be assessed by in vitro germination on a sucrose and agar medium (García and Egea, 1979; Hill et al., 1985; Parfitt and Almehdi, 1984; Weinbaum et al., 1984). The results of these assays correlated well with in vivo results obtained through fruit set determinations (Klungness et al., 1983; Loreti et al., 1979). The objective of this study was to evaluate pollen viability for four almond cultivars following storage for up to 12 months at $4,0,-20$ and $-80{ }^{\circ} \mathrm{C}$.

Received for publication14 June 2001. Accepted for publication 10 Aug. 2001. We thank the support of Spanish Ministry of Education and Culture in the stay of Pedro Martínez-Gómez and Encarnación Ortega in the United States.

'E-mail address: tmgradziel@ucdavis.edu. pareil, 'Ne Plus Ultra', 'Sonora' and 'Peerless', were used. Pollen was collected from flowers at the popcorn stage of development and then dehydrated for $48 \mathrm{~h}$ at $22{ }^{\circ} \mathrm{C}$ in a silica gel desiccator with a relative humidity (RH) of $<5 \%$ as measured by a Mannix model PTH8708 hygrometer (Mannix Testing \& Measurement, Lynbrook, N.Y.). Samples of $10 \mathrm{mg}$ were stored for up to 12 months in sealed $1.5-\mathrm{mL}$ eppendorf tubes at 4, 0, -20, and $-80{ }^{\circ} \mathrm{C}$ in controlled temperature chambers at the Univ. of California Fruit and Nut

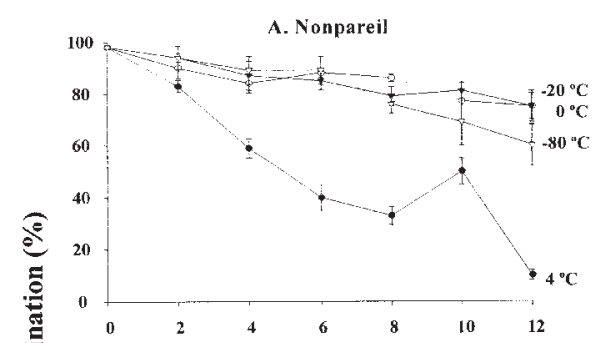
SD about mean.
Postharvest Research Lab., Dept. of Pomology, Davis, Calif. Pollen viability was tested at 2-month intervals using germination and growth on an artificial medium. Prior to germination tests, eppendorf tubes were gradually warmed to $24^{\circ} \mathrm{C}$ then placed for $1 \mathrm{~h}$ in a rehydration chamber at $\approx 96 \% \mathrm{RH}$ to avoid damage from moisture imbibition when pollen is exposed to the culture medium (Hoekstra, 1984; Barnabás and Kovács, 1997). Pollen was then dusted onto petri dishes containing $25 \mathrm{~mL}$ of culture medium [15\% sucrose, $1.5 \%$ agar, 100 ppm $\mathrm{H}_{3} \mathrm{BO}_{3}, 300 \mathrm{ppm}$ $\left.\mathrm{Ca}\left(\mathrm{NO}_{3}\right)_{2} \cdot 4 \mathrm{H}_{2} \mathrm{O}\right]$ (Brewbaker and Kwack, 1963; García and Egea, 1979; Parfitt and Almehdi, 1984; Weinbaum et al., 1984). Pollen on media was incubated at $24{ }^{\circ} \mathrm{C}$ for $6 \mathrm{~h}$, which was near optimum conditions for the in vitro germination and growth of almond pollen tubes (García and Egea, 1979; Weinbaum et al., 1984). Germination counts were made at $\times 40$ magnification (STEMI-SV8 Zeiss microscope; Carl Zeiss, New York). Pollen was scored as germinated when the length of the tube exceeded the pollen diameter (Ducon, 1968).

Four different fields of vision, each with an area of $12.5 \mathrm{~mm}^{2}$ and including $\approx 250-300$ grains, were examined per treatment. Results were analyzed by two-way analysis of variance (SAS Institute, 1989). Means were separated by Tukey's Studentized range test at $P<0.05$.

\section{Results and Discussion}

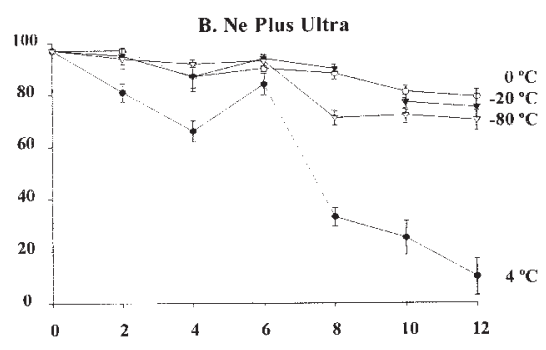
was $\geq 95 \%$ for all the cultivars (Fig. 1) and was generally higher than reported by others (García and Egea, 1979; Hill et al., 1985; Klungness et al., 1983; Loreti et al., 1979; Weinbaum et al., 1984). The decline in pollen viability with time was similar among cultivars (Fig. 1). Martínez-Gómez et al. (2000) reported comparable trends for short-term storage of al-

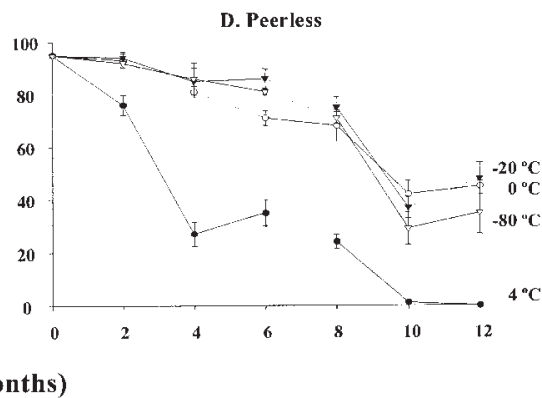

Time (months)

Fig. 1. Pollen germination of four almond cultivars stored up to 12 months at four temperatures. (Bars show 
mond pollen at $4{ }^{\circ} \mathrm{C}$. Interestingly, after storage at $4{ }^{\circ} \mathrm{C}$ from 6 to 10 months, increases of germination percentages were consistently observed. Similar increases in germination of stored pollen have been observed in our earlier testing of different germination media (unpublished data) and may represent the deterioration of a sporopollenin based germination inhibitor, as suggested by the work of Pimienta (1980).

Pollen viability decreased slightly to $\approx 90 \%$ after 2 months at $0,-20$, and $-80^{\circ} \mathrm{C}$, and to $80 \%$ at $4{ }^{\circ} \mathrm{C}$ in the four cultivars assayed. These results are consistent with MartínezGómez et al. (2000) who suggested $4{ }^{\circ} \mathrm{C}$ is suitable for almond pollen storage [ $20 \%$ relative humidity $(\mathrm{RH})]$ for up to 2 months. The viability of pollen stored at $4{ }^{\circ} \mathrm{C}$ decreased gradually to $8 \%$ in 'Nonpareil', $10 \%$ in ' $\mathrm{Ne}$ Plus Ultra', $50 \%$ in 'Sonora' and $0 \%$ in 'Peerless' by the end of the storage period. Pollen viability at the other three storage tempera-

Table 1. In vitro germination of pollen of four almond cultivars after 12 months storage at four temperatures.

\begin{tabular}{lcc}
\hline Cultivar & $\begin{array}{c}\text { Temp } \\
\left({ }^{\circ} \mathrm{C}\right)\end{array}$ & $\begin{array}{c}\text { Pollen } \\
\text { germination }(\%)^{2}\end{array}$ \\
\hline Nonpareil & 4 & $8 \mathrm{f}$ \\
& 0 & $76 \mathrm{ab}$ \\
& -20 & $77 \mathrm{ab}$ \\
Pooled means & -80 & $65 \mathrm{bc}$ \\
Ne Plus Ultra & 4 & $55 \mathrm{~b}$ \\
& 0 & $10 \mathrm{f}$ \\
& -20 & $82 \mathrm{a}$ \\
Pooled means & -80 & $76 \mathrm{ab}$ \\
Sonora & 4 & $59 \mathrm{bb}$ \\
& 0 & $50 \mathrm{~cd}$ \\
& -20 & $81 \mathrm{a}$ \\
Pooled means & -80 & $77 \mathrm{ab}$ \\
Peerless & 4 & $70 \mathrm{ab}$ \\
& 0 & $09 \mathrm{a}$ \\
& -20 & $45 \mathrm{de}$ \\
Pooled means & -80 & $46 \mathrm{de}$ \\
\hline
\end{tabular}

${ }^{2}$ Means in columns with the same letter are not significantly different $(P<0.05)$. tures remained above $70 \%$ in 'Nonpareil', 'Ne Plus Ultra', and 'Sonora' cultivars and near $40 \%$ in 'Peerless' (Fig. 1, Table 1). After 12 months, 'Peerless' had the lowest average germination (32\%) followed by 'Nonpareil'(55\%), 'Ne Plus Ultra' (59\%), and 'Sonora' (69\%) (Table 1). Differences among the cultivars and storage temperatures were statistically significant, but no significant interactions were identified.

Pollen viability following storage at $-80{ }^{\circ} \mathrm{C}$ was consistently lower (through not statistically separable) than that at 0 and $-20^{\circ} \mathrm{C}$ for the four cultivars assayed (Table 1). Polito and Luza (1988) observed a negative effect of cryopreservation of pollen in some pistachio cultivars at $-196{ }^{\circ} \mathrm{C}$ vs. $-20^{\circ} \mathrm{C}$ after 12 months of storage, possibly due to cellular lesions produced during freezing and thawing at the former temperature. Parfitt and Almehdi (1984) and Luza and Polito (1985), however, did not find a significant loss of viability following cryopreservation of pollen of almond and walnut cultivars in liquid nitrogen at $-196^{\circ} \mathrm{C}$ though final germination rates were variable.

In conclusion, pollen longevity following cold storage varied with almond genotype. Mechanisms responsible for these genetic differences remain poorly understood and are currently being investigated. Storage at $4{ }^{\circ} \mathrm{C}$ did not significantly decrease the pollen viability after two months. Successful pollen storage for longer periods of up to 1 year required temperatures at or below $0{ }^{\circ} \mathrm{C}$. Temperatures of $0,-20$, and $-80^{\circ} \mathrm{C}$, gave similar results after 1 year. The extra cost of storage at $-80{ }^{\circ} \mathrm{C}$, including the extra precautions required for warming and rehydrating stored pollen, may make storage temperatures of 0 to $-20{ }^{\circ} \mathrm{C}$ more convenient for longer storage of 2-12 months.

\section{Literature Cited}

Barnabás, B. and G. Kovács. 1997. Storage of Pollen. In: K.R. Shivanna and V.K. Sawnney (eds.). Pollen Biotechnology for crop production and improvement. Cambridge Univ. Press. 293-314.
Brewbaker, J.L. and B.H. Kwack. 1963. The essential role of calcium ion in pollen germination and pollen tube growth. Amer. J. Bot. 50:859-865.

Ducon, P. 1968. La fructification des arbres fruitiers. Etude de quelques caractères du pollen et de la biologie florale de l'Amandier e Pommier. Pomologie Française 5.

García, J.E. and L. Egea.1979. Influencia de la temperatura en la germinación del polen de variedades de almendro. An. Edaf. y Agrobiología 38:2181-2193.

Hill, S.J., D.W. Stephenson, and B.K. Taylor. 1985. Almond pollination studies: pollen production and viability, flower emergence and cross-pollination tests. Aust. J. Experimental Agr. 25:697704.

Hoekstra, F.A. 1984. Imbibitional injury in pollen. Plant Physiol. 74:815-821.

Jiang Y.S., and Z.J. Gao. 1989. Ultra-low temperature $\left(-196^{\circ} \mathrm{C}\right)$ storage of peach and pear pollen. Acta Agr. Shangai 5:1-8.

Klungness, M., R. Thorp, and D. Briggs. 1983. Field testing the germination of almond pollen (Рunиs dulcis). J. Hort. Sci. 58:229-235.

Loreti, F., R. Viti, and C. Xiloyannis. 1979. Prove di impollinazione incrociata e fertilità del polline di alcune cultivar di mandorlo. Frutta secca 116:379_ 391.

Luza, J.G. and V.S. Polito. 1985. In vitro germination and storage of English walnut pollen. Sci. Hort. 27:303-316.

Luza, J.G. and V.S. Polito. 1988. Cryopreservation of English walnut (Juglans regia L.) pollen. Euphytica 37:141-148.

Martínez-Gómez, P., T.M. Gradziel, E. Ortega, and F. Dicenta. 2000. Short-term storage of almond pollen. HortScience 35:1151-1152.

Parfitt, D.E. and A.A. Almehdi. 1984. Liquid nitrogen storage of pollen from five cultivated Prunus species. HortScience 19:69-70.

Pimienta, B.E. 1980. A study of the sexual reproduction in almond (Prunus amygdalus, Batsch L. cv Nonpareil) during the progamic phase. PhD Diss. Univ. of California, Davis.

Polito, V.S. and J.G. Luza. 1988. Low temperature storage of pistachio pollen. Euphytica 39:265269.

SAS Institute. 1989. SAS/STAT user's guide. SAS Inst., Cary, N.C.

Weinbaum, S.A., D.E. Parfitt, and V.S. Polito. 1984. Differential cold sensitivity of pollen grain germination in two Prunus species. Euphytica $33: 419-426$ 